\title{
Informing sea otter reintroduction through habitat and human interaction assessment
}

\author{
Dominique V. Kone ${ }^{1,4, *}$, M. Tim Tinker ${ }^{2}$, Leigh G. Torres ${ }^{3}$ \\ ${ }^{1}$ College of Earth, Ocean, and Atmospheric Science, Marine Mammal Institute, Oregon State University, \\ 2030 SE Marine Science Drive, Newport, OR 97365, USA \\ ${ }^{2}$ Department of Ecology and Evolutionary Biology, University of California, Santa Cruz, Santa Cruz, CA 95064, USA \\ ${ }^{3}$ Department of Fisheries and Wildlife, Marine Mammal Institute, Oregon State University, 2030 SE Marine Science Drive, \\ Newport, OR 97365, USA \\ ${ }^{4}$ Present address: California Ocean Science Trust, 1111 Broadway, Oakland, CA 94607, USA
}

\begin{abstract}
Sea otters Enhydra lutris have been absent from Oregon, USA, following their extirpation over a century ago. Stakeholder groups and native tribes are advocating for reintroduction to restore historic populations. We investigated the potential for successful reintroduction by: (1) estimating expected equilibrium sea otter densities as a function of habitat variables to assess sea otter habitat in Oregon; and (2) spatially relating areas of high expected densities to human activities (e.g. fisheries, recreation, vessel activity, protected areas) to anticipate potential disturbance or fishery resource competition. We estimated that $4538(1742-8976 ; 95 \% \mathrm{CI})$ sea otters could exist in Oregon, with higher expected abundance $(\mathrm{N}=1551)$ and densities $\left(\bar{x}=2.45 \mathrm{~km}^{-2}\right)$ within the southern region. Most core habitat areas $(97 \%)$, representing clusters of high expected densities, overlapped with some form of human activity. While commercial shipping and tow lanes overlapped little $(1 \%)$ with core habitat areas, recreational activities $(58 \%)$ and fisheries $(76 \%)$ had a higher degree of overlap, posing higher disturbance risk. We anticipate higher resource competition potential with the commercial red sea urchin fishery ( $67 \%$ of harvest areas) than the commercial Dungeness crab fishery ( $9 \%$ of high-catch crabbing grounds). Our study presents the first published carrying capacity estimate for sea otters in Oregon and can provide population recovery targets, focus attention on ecological and socioeconomic considerations, and help to inform a recovery plan for a resident sea otter population. Our findings suggest current available habitat may be sufficient to support a sea otter population, but resource managers may need to further investigate and consider whether current human activities might conflict with reestablishment in Oregon, if plans for a reintroduction continue.
\end{abstract}

KEY WORDS: Sea otter - Enhydra lutris · Oregon - Reintroduction · Habitat - Carrying capacity · Fisheries $\cdot$ Conservation

\section{INTRODUCTION}

Throughout history, humans have exploited wildlife populations, and these activities may partially explain Earth's sixth mass extinction (Barnosky et al. 2011, Dirzo et al. 2014). Well-known examples of exploitive practices include near collapses in global whale populations due to international whaling

\footnotetext{
${ }^{*}$ Corresponding author: dom.kone@oceansciencetrust.org
}

(Clapham et al. 1999) and over-fished cod stocks along the US northeast coast (Hutchings \& Myers 1994, Myers et al. 1997). As biodiversity loss has accelerated, the importance of species diversity to ecosystem function, resilience, and services has become apparent (Cardinale et al. 2002, Elmqvist et al. 2003, Downing \& Leibold 2010). Biodiversity loss thus represents a prominent threat to environmental

() The authors 2021. Open Access under Creative Commons by Attribution Licence. Use, distribution and reproduction are unrestricted. Authors and original publication must be credited. 
sustainability. Recovery of at-risk species, particularly species vital to ecosystem function, can help maintain ecosystem integrity (Soulé et al. 2003). Environmental managers enlist a range of strategies to facilitate at-risk species recovery, such as establishing protected areas, moving threatened populations into captivity, or conducting reintroductions and reinforcements (Briggs 2009).

Sea otters Enhydra lutris were once distributed along most North Pacific Ocean coastlines from Japan to Baja California, Mexico, but were extirpated from most of their historic range during the peak of the maritime fur trade from the mid-1700s to mid-1800s (Kenyon 1969). Recovery occurred slowly over the first half of the 20th century; however, a significant boost to recovery occurred in the late 1960s when resource managers translocated sea otters from Amchitka Island and Prince William Sound, Alaska, to Southeast Alaska, British Columbia, Washington, and Oregon. Most of these translocation efforts were successful, and populations in these areas are now abundant and thriving. A notable exception was the translocation effort to Oregon, where the founding population gradually declined from reintroduction in 1970-1971 ( $\mathrm{N}=93$ otters) to 1981, when only 1 otter was observed during routine surveys, after which the population was expected to disappear (Jameson et al. 1982). No consensus exists for the cause of failure of the Oregon population, but several hypothesized factors include lack of appropriate habitat or prey, human disturbance, or sea otter emigration due to homing behavior (Jameson et al. 1982). Presently, stakeholder groups and native tribes are advocating for a second attempt at sea otter reintroduction to Oregon, arguing that this action could achieve several objectives, including: (1) aiding recovery efforts for a species of conservation concern; (2) restoring coastal food web structure and function; (3) provisioning ecosystem services, including economic or intrinsic/recreational benefits; and (4) restoring lost cultural and tribal traditions and ecological connections.

Species reintroductions represent an important tool for managers charged with recovering at-risk species (Clark \& Westrum 1989, Seddon et al. 2007). There have been several notable cases where translocations have contributed to species recovery, including the previously mentioned sea otter translocations across the North Pacific Ocean, red deer Cervus elaphus to central Portugal (Valente et al. 2017), and gray wolves Canis lupus to Yellowstone National Park, USA (Smith \& Guernsey 2002, Ripple \& Beschta 2003). Species reintroductions are also risky because uncertainty surrounds whether the species will reestablish in their release area (Sarrazin \& Barbault 1996). Habitat suitability assessments can reduce this uncertainty by identifying areas of unoccupied habitats that are likely to sustain the introduced species and foster population growth over time (Cheyne 2006). Predator populations and population growth are often limited by prey availability. Therefore, habitat models can be used to identify and predict areas of unoccupied habitats that are likely to contain adequate prey to sustain the predator.

Sea otters have been absent from Oregon waters for more than $100 \mathrm{yr}$, during which time nearshore habitats have experienced substantial change. A variety of human activities now occur along the Oregon coast, including fisheries, recreation, and shipping (Norman et al. 2007, LaFranchi \& Daugherty 2011), which could disturb sea otters or make habitats less hospitable. At present there has been no systematic assessment of the potential for sea otters to reestablish in Oregon. Using predictive models to evaluate the potential for sea otter recovery in different sites can help fill this knowledge gap; such models require an understanding of habitat features that facilitate effective sea otter foraging and knowledge of current nearshore habitats in Oregon. Luckily, sea otter habitat-use patterns and foraging activities are well documented in other regions (e.g. Ostfeld 1982, Laidre et al. 2009, Hughes et al. 2013, Lafferty \& Tinker 2014), and this information can be leveraged for consideration of the potential for sea otter recovery in Oregon.

Sea otters are typically found within shallow and intertidal rocky habitats, where they forage for benthic macroinvertebrates such as sea urchins, sea snails, bivalves, and crabs (Estes et al. 1982, Ostfeld 1982, Laidre \& Jameson 2006, Newsome et al. 2009). Canopy-forming and understory macroalgae (i.e. kelp, seaweed) also provide important habitat for prey species as well as protected resting habitat for sea otters (Estes \& Palmisano 1974, Estes et al. 1982, Nicholson et al. 2018). In addition to rocky and kelpdominated habitats, sea otters also use soft-sediment habitats on the outer coast and within estuaries (Riedman \& Estes 1990, Hughes et al. 2013, 2019, Hale et al. 2019). Sea otters have been infrequently observed hauling out on shore to rest, groom, and forage. This behavior appears to be more common on marshes within Elkhorn Slough, California, and on sand and mud bars in Alaska, and is much less observed along outer coastal shorelines (Kenyon 1969, Garshelis \& Garshelis 1984, Faurot 1985, Green \& Brueggeman 1991, Eby et al. 2017). The seaward distribution of sea otters is limited by their maximum diving capacity of $100 \mathrm{~m}$ depth (Bodkin et al. 2004, 
Thometz et al. 2016), although most dives occur within $40 \mathrm{~m}$ depth. Within their nearshore distribution, sea otter densities have a non-linear relationship with depth, where densities peak around a model depth of $15 \mathrm{~m}$, and gradually decline as depth increases or decreases (Tinker et al. 2017). The slope and width of the continental shelf can dictate how dense or spread out populations are across space (Tinker et al. 2021). Relative to other marine predators, sea otters have extremely high metabolisms and almost no capacity for energy storage in fat tissue, and thus require anywhere from 25 to $30 \%$ of their own body weight in food every day (Costa \& Kooyman 1982, Riedman \& Estes 1990). Their extreme dependency on high energy prey means identifying high quality foraging habitat within their depth limits is imperative to facilitating successful reintroduction.

Population growth and survival are 2 metrics used to assess the performance and potential success of reintroduction efforts and species reestablishment (IUCN/SSC 2013). Both lethal (i.e. mortality) and non-lethal (e.g. human disturbance, resource competition) stressors may reduce or hinder population growth and survival. Some causes of sea otter mortality (e.g. white shark attacks, cardiac arrest, infectious diseases, fishing gear entanglements, etc.) are well studied and directly limit population growth (Estes et al. 2003, Kreuder et al. 2003, Tinker et al. 2016). Yet, the population-level consequences of non-lethal stressors, such as human disturbance, are more difficult to assess. Conceptually, this understanding requires evidence that (1) exposure to a stressor causes a behavioral or physiological response, (2) those responses alter internal health (e.g. homeostasis), (3) the internal health alterations influence individual vital rates (e.g. survival, fecundity, growth), and (4) a significant number of individuals experience these impacts to vital rates resulting in population-level effects (National Academies of Sciences, Engineering, and Medicine 2017, Pirotta et al. 2018). As with many other marine mammals that are sensitive to human disturbance (Williams et al. 2006, Tyack 2008), sea otters exhibit physiological and behavioral responses to disturbance: for example, recreational boating (e.g. kayaks, dive boats, jet skis) can cause sea otters to increase their activity and spend less time resting, with implications for their metabolic costs (Curland 1997, Barrett 2019). To meet their metabolic demands, sea otters spend most of their daily time budget foraging and resting (Yeates et al. 2007, Thometz et al. 2014). Therefore, any deviation from these behavioral states impacts their internal health and could be energetically costly. It is unclear whether, and to what degree, disturbance-induced behavior and physiological responses in sea otters are great enough to produce population-level consequences. Regardless, human disturbance has been, and continues to be, a concern for sea otter survival and conservation (US Fish and Wildlife Service 2003) and should be accounted for when deciding if and where sea otters should be reintroduced in Oregon.

Fisheries add a further complication due to concerns regarding competition and ecosystem impacts of sea otter foraging on certain shellfish species important to fisheries (Johnson 1982). Sea otters exhibit strong top-down pressures by reducing prey densities and size via predation (Estes et al. 1978, Estes \& Duggins 1995), and sea otter-driven reductions in fishery-dependent prey species have been documented (Garshelis \& Garshelis 1984, Garshelis et al. 1986, Larson et al. 2013, Carswell et al. 2015). Importantly, a network of 5 no-take marine reserves was established along the Oregon coast in 2013; this reserve network restricts human activity and could alleviate or prevent potential disturbance to sea otters and resource competition with fisheries, in the event of a sea otter reintroduction.

Here we summarize multiple data sets and conduct analyses aimed at informing management decisions related to sea otter reintroduction to Oregon. Our study objectives are (1) to assess habitat presence and quality along the Oregon coast; and (2) to determine the potential for recovering sea otter populations to spatially overlap with select human activities that might cause resource competition or disturbance to sea otters. We expect that the results of our study will help managers assess the feasibility for a successful sea otter reintroduction to Oregon and identify potential next steps in the process.

\section{MATERIALS AND METHODS}

\subsection{Study area}

The study area includes all nearshore coastal waters in Oregon, USA, from the Columbia River in the north to the Oregon-California state border in the south. The Oregon coastline is comprised of alternating sandy beaches and complex rocky habitats, with several bays and estuaries. The shallow, gradual-sloping continental shelf extends 17 to $74 \mathrm{~km}$ from the shoreline and is comprised of hard and soft benthic substrates (Kulm \& Fowler 1974). The outer coast supports several macroinvertebrate prey items 
for sea otters including urchins Strongylocentrotus spp., abalone Haliotis spp., Dungeness crab Metacarcinus magister, and razor clams Siliqua patual. A number of small and large coastal estuaries also support invertebrate prey for sea otters, including bay clams (Tresus, Saxidomus, Leukoma, Mya spp.) and various crab species (ODFW 2006). Kelp canopies along the outer coast are primarily composed of bull kelp Nereocystis luetkeana and occur in rocky habitats (Mackey 2006, Springer et al. 2007) along the southern coastline. Eelgrass Zostera spp. is the dominant vegetation in estuaries (Sherman \& DeBruyckere 2018). Both kelp forests and eelgrass beds provide habitat for important sea otter prey species as well as resting habitat for sea otters.

\subsection{Habitat-based population model}

To investigate the presence and quality of sea otter habitat in Oregon, we adapted and applied a recently developed model of habitat-specific population potential for sea otters in California (hereafter referred to as the CA model; Tinker et al. 2021). The spatial proximity and overall similarity of coastal habitats in Oregon and California suggested that results of the CA model can be reasonably extrapolated to Oregon. In brief, Bayesian methods were used to fit a state-space model of density-dependent population growth, in which local carrying capacity $(K)$ was predicted as a function of a suite of local habitat features and environmental variables (henceforth, habitat variables) from 0 to $60 \mathrm{~m}$ depth. Habitat-density relationships (henceforth, parameters; Table 1) were estimated by fitting the CA model to a time series of annual survey counts of sea otters at known geographic locations, collected using shore-based and aerial surveys (from 1983 to 2017, except 2011), and augmented by cause-of-death data from stranded animals (Tinker et al. 2021). Using the joint posterior distributions from the CA model (Table 1), expected density at $K$ can then be projected at the scale of a $100 \mathrm{~m}$ spatial grid, based on local habitat characteristics that have been summarized over the same spatial grid. In addition to mean point estimates, model projections include the combined uncertainty associated with unexplained environmental and demographic variation, as well as parameter uncertainty. Here, we applied the parameters estimated from the CA model to spatial data layers of the same suite of habitat variables in Oregon to project localized sea otter densities and abundance at carrying capacity within the study area. The CA model parameters were applied to Oregon habitat variables and used to project sea otter densities in the same manner as the CA model, with identical variables, coefficients, and functions. Further details on the CA model design, development, and Bayesian methods are presented in Tinker et al. (2021).

\subsection{Habitat variable data layers}

We obtained spatial layers for each Oregon habitat variable from publicly available sources (Table 2 ) and converted all layers to a $100 \mathrm{~m}$ grid using standard lin-

Table 1. Parameters estimated from the Bayesian state-space habitat model for sea otters in California and applied in the Oregon model, including a description of each parameter, and the mean $(\bar{x})$, standard deviation (SD), and $95 \%$ confidence interval (CI) of the fitted posterior distribution. Parameters were estimated in 2019 using sea otter survey data from 1983 to 2017, except 2011. Table adapted from Tinker et al. (2021). K: local carrying capacity

\begin{tabular}{|c|c|c|c|c|c|}
\hline $\begin{array}{l}\text { Para- } \\
\text { meter }\end{array}$ & Description & $\bar{x}$ & SD & $\begin{array}{l}\text { Lower CI } \\
(95 \%)\end{array}$ & $\begin{array}{l}\text { Upper CI } \\
(95 \%)\end{array}$ \\
\hline$\kappa_{\mathrm{s}}$ & $\begin{array}{l}\text { Intercept; mean log-density in } \\
\text { soft sediment habitats }\end{array}$ & 0.5613 & 0.3025 & -0.0297 & 1.1749 \\
\hline$\kappa_{\mathrm{e}}$ & $\begin{array}{l}\text { Alternative intercept; mean } \\
\text { log-density in estuaries }\end{array}$ & 1.2238 & 0.7384 & -0.2421 & 2.6498 \\
\hline$D^{*}$ & $\begin{array}{l}\text { modal depth (at which mean } \\
\text { densities are highest) }\end{array}$ & 5.7711 & 0.6978 & 4.4123 & 7.1518 \\
\hline$\beta_{1}$ & $\begin{array}{l}\text { effect of decreasing depth } \\
\text { from } D^{*} \text { on log- } K\end{array}$ & 3.4262 & 1.2871 & 1.3157 & 5.9135 \\
\hline$\beta_{2}$ & $\begin{array}{l}\text { effect of increasing depth } \\
\text { from } D^{*} \text { on log-K}\end{array}$ & 0.1266 & 0.0072 & 0.1124 & 0.1409 \\
\hline$\alpha_{\mathrm{PR}}$ & $\begin{array}{l}\text { effect of increasing proportion } \\
\text { of rocky substrate on log- } K\end{array}$ & 1.7268 & 0.1346 & 1.4499 & 1.9786 \\
\hline$\alpha_{\mathrm{PK}}$ & $\begin{array}{l}\text { effect of increasing proportion } \\
\text { of kelp cover on log- } K\end{array}$ & 2.6727 & 0.1497 & 2.3820 & 2.9681 \\
\hline$\alpha_{\mathrm{DSR}}$ & $\begin{array}{l}\text { effect of deviations from mean } \\
\text { slope on log- } K \text {, linear response }\end{array}$ & 0.1816 & 0.0917 & 0.0006 & 0.3592 \\
\hline$\alpha_{\mathrm{DSR} 2}$ & $\begin{array}{l}\text { effect of deviations from mean } \\
\text { slope on log- } K \text {, quadratic } \\
\text { response }\end{array}$ & 0.2051 & 0.0637 & 0.0787 & 0.3283 \\
\hline$\alpha_{\mathrm{OFSH}}$ & $\begin{array}{l}\text { effect of increasing distance } \\
\text { from shore beyond } 1 \mathrm{~km} \text { (i.e. } \\
\text { 'far offshore effect') on log-K }\end{array}$ & -0.6058 & 0.1713 & -0.9334 & -0.2618 \\
\hline$\alpha_{\mathrm{NPP}}$ & $\begin{array}{l}\text { effect of increasing net primary } \\
\text { production on log- } K\end{array}$ & 0.5537 & 0.1305 & 0.3002 & 0.8117 \\
\hline$\sigma_{K}$ & $\begin{array}{l}\text { magnitude of random variation } \\
\text { in log- } K \text { among regions }\end{array}$ & 0.9343 & 0.2769 & 0.4800 & 1.5610 \\
\hline
\end{tabular}


Table 2. Oregon spatial habitat layers, including resolution, interpolation method, and source information. Cell units represent the calculated values assigned to each $100 \mathrm{~m}$ grid cell following interpolation. NPP: net primary productivity. NA: Not applicable

\begin{tabular}{|c|c|c|c|c|}
\hline $\begin{array}{l}\text { Habitat } \\
\text { variable }\end{array}$ & $\begin{array}{l}\text { Spatial } \\
\text { resolution }\end{array}$ & $\begin{array}{l}\text { Interpolation } \\
\text { method }\end{array}$ & $\begin{array}{l}\text { Cell } \\
\text { units }\end{array}$ & References \\
\hline Bathymetry & $90 \mathrm{~m}$ cells & Bi-linear & $\mathrm{m}$ & US Coastal Relief Model (NOAA National Geophysical Data Center 2003 a,b) \\
\hline Kelp canopy & Polygons & Max. area & Proportion kelp cover & Marine Resource Program (ODFW 2011) \\
\hline Benthic substrate & Polygons & Max. area & Proportion hard & Active Tectonics \& Seafloor Mapping Lab (Goldfinger et al. 2014) \\
\hline NPP & $2000 \mathrm{~m}$ cells & Bi-linear & $\mathrm{mg} \mathrm{C} \mathrm{m}^{-2} \mathrm{~d}^{-1}$ & $\begin{array}{l}\text { Vertically Generalized Production Model (O'Malley, http://sites.science. } \\
\text { oregonstate.edu/ocean.productivity; accessed Nov 2019) }\end{array}$ \\
\hline Estuaries & Polygons & Max. area & Presence & Scranton (Scranton 2004) \\
\hline Shoreline & Line & NA & Presence & Oregon Department of Fish \& Wildlife (ODFW 2005a,b) \\
\hline
\end{tabular}

ear interpolation techniques. We spatially combined 2 bathymetry layers to estimate variation in depth $(D)$ over the study area. Kelp canopy data was a composite of multiple aerial kelp biomass surveys conducted in 1990, 1969-1999, and 2010, and we used these layers to calculate proportional kelp cover (PK) for each grid cell. Benthic substrate was classified (i.e. hard, mixed, soft) following seafloor descriptions of Greene et al. (1999). To quantify the proportional cover of hard substrate (PR) at each grid cell, we reclassified mixed substrate to hard because we observed a high degree of overlap between kelp canopies and mixed substrate, suggesting mixed substrate may functionally act as hard. We estimated net primary productivity (NPP) using an index for mean monthly NPP, following methods identical to those of Tinker et al. (2021). NPP data derived from a chlorophyll-based Vertically Generalized Production Model and represented temperature-dependent, chlorophyll-specific photosynthesis (Behrenfeld \& Falkowski 1997). We filled in missing nearshore cells using $\mathrm{k}$ - $\mathrm{d}$ tree, a nearest neighbor interpolation method (Bhatia \& Vandana 2010), to calculate an average NPP value based on the 5 nearest cell values. Sea otter densities within estuaries can differ from soft sediment habitats on the outer coast (Silliman et al. 2018), so we identified estuary habitats using a categorical switch variable 'EST' (where EST = 1 for areas within estuaries, 0 for outer coast). We only included estuary reaches classified as water as potential sea otter habitat, and we did not include the Columbia River in the predictions as it is unclear if this large estuary will support high otter densities. Several land polygons disagreed on shoreline position, so we merged a rocky and sandy shoreline layer to create a more precise shoreline and land layer. We conducted all spatial analyses and interpolations in ESRI's ArcGIS v10.6.1.

We incorporated depth and distance-to-shore effects following methods of Tinker et al. (2021). Because there is a strong, non-linear relationship between log distance-to-shore (Euclidean) and depth $\left(D_{g}\right)$ at any grid cell $(g)$, we detrended distance-to-shore $\left(\mathrm{DS}_{g}\right)$ values using the following equation:

$$
\log \left(\mathrm{DS}_{g}+1\right) \sim 1.669 \times D_{g}^{0.289}+3.123
$$

The values in the least-squares equation were estimated using maximum likelihood methods and fit to data for the California coast (Tinker et al. 2021); very similar values were obtained from a similar analysis in Oregon, but we use the California values so as to retain the same habitat-density relationship parameters. The resulting distance to shore residuals $\left(\mathrm{DSR}_{g}\right)$ are independent of depth and effectively provide an index of benthic slope: positive values correspond to areas where distance to shore is greater than average relative to depth (shallow slope), and negative values represent areas where distance to shore is lower than average relative to depth (steeper slope). In Oregon, 2 reefs (Orford and Blanco Reef) have offshore island clusters that cause the seafloor to decrease in depth as distance-to-shore increases, complicating the relationship between depth and distance to shore. To account for this, we calculated distanceto-shore from these islands to appropriately assign slope effects within these reefs. We excluded any islands outside these reefs.

Parts of the Oregon continental slope extend far offshore, where shallow depths would theoretically be accessible to sea otters, but sea otters have not been observed to regularly use these areas in California (Tinker et al. 2021). Accordingly, both the CA (Tinker et al. 2021) and Oregon models include this additional variable to allow for an offshore effect (OFSH) that can mediate predicted densities further offshore.

$$
\mathrm{OFSH}_{g}=\left[\max \left(0, \mathrm{DS}_{g}-1000\right) / 5000\right]^{2}
$$

This offshore variable has no effect within $1 \mathrm{~km}$ of shoreline, but can have increasingly large effects for areas $>5 \mathrm{~km}$ offshore. 
To account for the non-linear relationship between otter densities and depth, we included the following depth function and variables from the CA model (Tinker et al. 2021):

$$
\begin{gathered}
f\left(D_{g} \mid \beta_{\mathrm{i}}, D^{*}\right)=-0.01 \times\left[\beta_{1} \times \max \left(0, D^{*}-D_{g}\right)\right. \\
\left.+\beta_{2} \times \max \left(0, D_{g}-D^{*}\right)^{2}\right]
\end{gathered}
$$

where $D^{*}$ represents the modal depth and $\beta_{1}$ and $\beta_{2}$ control the rates at which density changes as depth varies inshore and offshore (respectively) of this modal depth.

Lastly, to account for the fact that equilibrium sea otter densities reflect the quality of habitat available to individual sea otters within their home ranges, not just at a single point in space, we applied a $4 \mathrm{~km}$ moving average smoothing window to all habitat variables, following Tinker et al. (2021). For each sequential $1 \mathrm{~m}$ isobath, habitat variables were averaged across all cells within a $4 \mathrm{~km}$ smoothing window (i.e. the smoothed cell values for each habitat variable were specific to depth). The width of the smoothing window (4 km) was based on observed sea otter core home range size (Ralls et al. 1995, Tarjan \& Tinker 2016).

\subsection{Projecting carrying capacity}

To predict otter densities (independents [i.e. adults] $\mathrm{km}^{-2}$, excluding dependent pups) at carrying capacity on the outer coast of Oregon, we solved the following equation:

$$
\log \left(K_{g}\right)=\kappa_{\mathrm{s}}+\sum_{j} \alpha_{j} H_{j, g}+f\left(D_{g} \mid \beta_{i,} D^{*}\right)+\zeta_{g \mid p}
$$

Each grid cell $(g)$ was assigned an expected otter density at carrying capacity $\left(K_{g}\right)$ as a function of the mean log otter density in outer coast soft sediment habitat (intercept $\kappa_{\mathrm{si}}$ Table 1 ), the above-described net effect of habitat variables $\left(H_{j, g}\right.$ corresponds to EST, $\mathrm{PK}, \mathrm{PR}, \mathrm{DSR}, \mathrm{DSR}^{2}$, NPP and OFSH; see Section 2.3 and Table 1), the non-linear depth function (Eq. 3), and a random effect $\left(\zeta_{g \mid p}\right)$ representing unexplained deviations from mean expected otter densities at grid cells within a region $(P)$ (regions described below). The random effect term was normally distributed with mean of 0 and standard deviation parameter $\left(\sigma_{K}\right)$, and we note that for the Oregon model, this term is centered on 0 for all regions (since the specific random effects for the CA model were conditioned upon the data used to fit that model), and thus does not affect the mean projected densities; however, its inclusion does add appropriate levels of predictive uncertainty to the model projections. The effects of habitat variables are controlled by parameters, $\alpha_{j}$, which can be interpreted as log ratios, or the log proportional increase or decrease in otter densities associated with a unit change in each habitat variable. In the CA model, inclusion of these habitat variables was found to reduce the unexplained variance in equilibrium density by $42 \%$ as compared to an intercept-only model, and by $17 \%$ as compared to an intercept plus depth model (Tinker et al. 2021). Therefore, inclusion of these habitat effects is expected to similarly improve our predictive power to estimate equilibrium densities in Oregon.

To estimate carrying capacity for Oregon, we evaluated Eq. (4) using the Oregon habitat variables, and with parameter values set by iteratively drawing 10000 samples from the joint posterior distribution estimated for CA using MCMC methods (Table 1, Tinker et al. 2021). We thereby calculated a posterior distribution of $K_{g}$ values for the Oregon coast, which we summed across all grid cells to obtain a posterior distribution for total expected abundance at $\mathrm{K}$ for both the outer coast and estuaries. We then combined abundance estimates for estuaries and outer coast to determine total predicted sea otter abundance at carrying capacity for the entire Oregon coast. We divided the study area into 3 regions (north, central, and south; Fig. 1), of approximately similar sizes (see Table 5) using the same regional boundaries as Jameson (1974), and we compared predictions between regions. By using the full joint posterior distribution of the parameters from the CA model (Table 1), and including the additional variance associated with random effects $\left(\zeta_{g \mid p}\right)$, we were able to realistically quantify uncertainty for each region in terms of credible intervals (CI, $\alpha=0.05)$. For the outer coast, we reported mean densities out to the $40 \mathrm{~m}$ isobath, for consistency with previous studies on sea otter density along the US West Coast (Laidre et al. 2001, Tinker et al. 2021).

\subsection{Core habitat areas of high sea otter densities}

To anticipate locations where sea otters and human activities may interact in Oregon, we identified core habitat areas where clusters of high sea otter densities are most likely to occur. To identify high density habitat areas, we log-transformed the predicted equilibrium density values for all grid cells to obtain a more normal data distribution and extracted those cells having log-densities $>2$ standard deviations above the mean (4.36 otters per $\mathrm{km}^{2}$ ). We grouped high-density cells within $1 \mathrm{~km}$ of each other to 

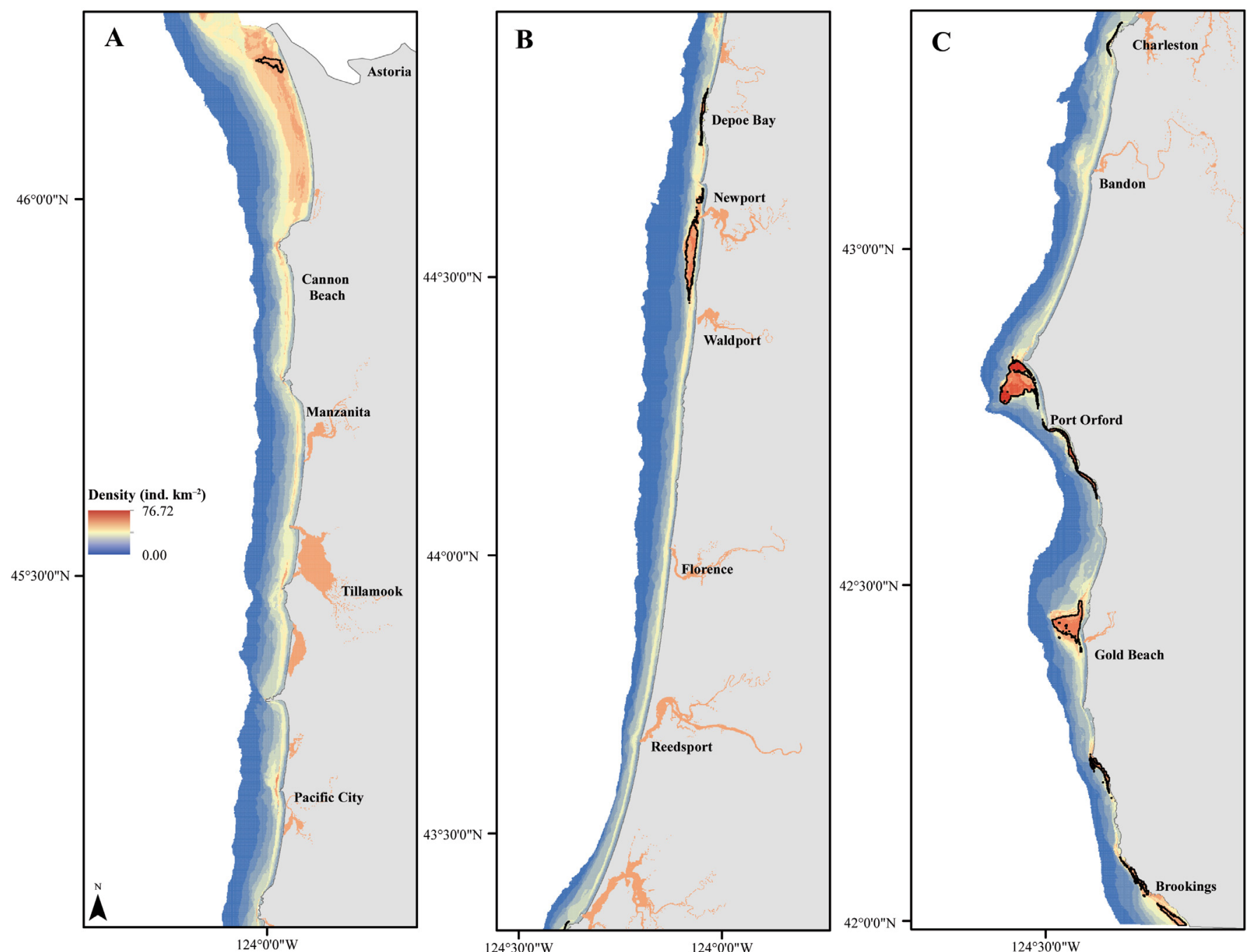

Fig. 1. Predicted sea otter densities along the outer coast and in estuaries of Oregon, USA, for the (A) north, (B) central, and (C) south regions. Density values are visualized using natural breaks (Jenks) with 12 data classes. Core habitat areas are outlined in black and transposed over high-density values

identify contiguous core habitat areas, which we delineated using the 'Raster to Polygon' tool in ESRIs ArcGIS. For each resulting core habitat area, we summed predicted densities to calculate total abundance. We then excluded core habitat area polygons whose combined abundance was lower than a threshold of 8 to identify core habitat areas likely to support relatively high sea otter abundances. We set this abundance threshold at 8 by (1) identifying all core habitat areas at or near historical sea otter foraging locations (Simpson, Orford, and Blanco Reefs) from the first translocation (Jameson 1974), and then (2) identifying the single core habitat area with the lowest abundance at those historical foraging locations, to represent or suggest a minimum viable population size.

\subsection{Human activities}

We assessed the potential for interaction (i.e. resource competition with fisheries and human disturbance to sea otters) between sea otters in Oregon and 3 types of human activities: fisheries, non-recreational vessel traffic, and protected areas. We collected logbook landings data for the 10 most recent fishing seasons for a few commercial and recreational fisheries (Table 3). To protect fishermen confidentiality, data do not include harvest from fishing grounds where relatively few vessels were present. However, harvest data do represent the vast majority of fishery landings over this time period. We selected fisheries for target species that (1) are commonly consumed by sea otters and likely to be consumed in 
Table 3. Interaction potential between sea otters and human activities, including potential sources of disturbance, in Oregon, USA. Data layer descriptions and sources provided. Direct overlap and proximity metrics represent how interaction potential between sea otters and human activities were measured for each activity, while interaction level reports the calculated interaction potential for those associated metrics. Any ratios reported under interaction level are the proportions of activity or habitat spatial units (i.e. polygons, cells, lines) that interact with each other. NA: not applicable

\begin{tabular}{|c|c|c|c|c|c|c|c|}
\hline Activity & Data layer & $\begin{array}{c}\text { Spatial } \\
\text { resolution units }\end{array}$ & Value & $\begin{array}{c}\text { Direct } \\
\text { overlap metric }\end{array}$ & $\begin{array}{c}\text { Interaction } \\
\text { level }\end{array}$ & $\begin{array}{l}\text { Proximity } \\
\text { metric }\end{array}$ & $\begin{array}{l}\text { Interaction } \\
\text { level }\end{array}$ \\
\hline \multirow[t]{3}{*}{ Fisheries } & $\begin{array}{l}\text { Dungeness crab } \\
\text { (commercial) }^{\mathrm{a}}\end{array}$ & $\begin{array}{l}2 \mathrm{~nm} \text { cells } \\
(\mathrm{N}=40)\end{array}$ & $\begin{array}{l}\text { Annual crab } \\
\text { removals } \\
(2007-2017)\end{array}$ & $\begin{array}{l}\text { Activity } \\
\text { overlap }\end{array}$ & Yes $(2 / 40)$ & $\begin{array}{c}\% \text { activity } \\
\text { within } 2 \mathrm{~km}\end{array}$ & $9 \%$ (area) \\
\hline & $\begin{array}{l}\text { Red sea urchin } \\
\text { (commercial) }^{\mathrm{a}}\end{array}$ & $\begin{array}{c}\text { Harvest area } \\
\text { polygons }(\mathrm{N}=13)\end{array}$ & $\begin{array}{l}\text { Annual pounds } \\
\text { (2009-2018) }\end{array}$ & $\begin{array}{l}\text { Activity } \\
\text { overlap }\end{array}$ & Yes $(9 / 13)$ & $\begin{array}{c}\% \text { activity } \\
\text { within } 2 \mathrm{~km}\end{array}$ & $67 \%$ (area) \\
\hline & $\begin{array}{c}\text { Abalone } \\
\text { (recreational) }^{\mathrm{a}}\end{array}$ & $\begin{array}{l}\text { Harvest zone } \\
\text { lines }(\mathrm{N}=8)\end{array}$ & $\begin{array}{l}\text { Total ind. } \\
(2008-2017)\end{array}$ & $\begin{array}{l}\text { Activity } \\
\text { overlap }\end{array}$ & Yes (8/8) & NA & NA \\
\hline \multirow[t]{3}{*}{ Disturbance } & Recreation $^{\mathrm{s}}$ & $1600 \mathrm{~m}$ cells & Presence & $\begin{array}{l}\% \text { habitat } \\
\text { within }\end{array}$ & $58 \%$ & $\begin{array}{c}\text { Habitat } \\
\text { within } 2 \mathrm{~km}\end{array}$ & Yes $(10 / 10)$ \\
\hline & $\begin{array}{c}\text { Commercial } \\
\text { shipping \& tow } \\
\text { lanes }{ }^{\mathrm{C}, \mathrm{d}}\end{array}$ & Lane polygons & Presence & $\begin{array}{l}\% \text { habitat } \\
\text { within }\end{array}$ & $1 \%$ & $\begin{array}{c}\text { Habitat } \\
\text { within } 2 \mathrm{~km}\end{array}$ & Yes $(3 / 10)$ \\
\hline & Fishing ports ${ }^{\mathrm{e}}$ & Port points $(\mathrm{N}=12)$ & Presence & NA & NA & $\begin{array}{c}\text { Activity } \\
\text { within } 2 \mathrm{~km}\end{array}$ & Yes $(5 / 12)$ \\
\hline $\begin{array}{l}\text { Protected } \\
\text { areas }\end{array}$ & $\begin{array}{l}\text { Marine } \\
\text { reserves }^{\mathrm{f}}\end{array}$ & $\begin{array}{c}\text { Reserve } \\
\text { polygons }(\mathrm{N}=5)\end{array}$ & Presence & $\begin{array}{l}\% \text { habitat } \\
\text { within }\end{array}$ & $2 \%$ & $\begin{array}{c}\text { Activity } \\
\text { within } 2 \mathrm{~km}\end{array}$ & Yes $(2 / 5)$ \\
\hline
\end{tabular}

Oregon (Ostfeld 1982), and (2) are valued by local economies and/or conservation and, therefore, present an opportunity for resource competition (ODFW 2017a, 2019). We identified 'high-catch crabbing grounds' as areas having harvests that were 2 standard deviations above the mean of the log-transformed commercial Dungeness crab logbook data. We included recreational data on human-powered (i.e. kayaking, surfing, swimming, scuba, snorkeling, and skimboarding) and wildlife-viewing activities reported through an opt-in internet survey where respondents identified the type and location of coastal activities they participate in (LaFranchi \& Daugherty 2011). Responses were spatially joined and displayed in polygon planning units used in Oregon's Territorial Sea Plan. We assessed potential non-recreational vessel activity by combining commercial shipping lanes, tugboat tow lanes, and ports that provide facilities for large ships and commercial fishing boats (Hesselgrave et al. 2011). We included 1 additional port (Newport), which was missing from this dataset, with known commercial fishing processing facilities. We also assessed the 5 no-take marine reserves in Oregon (Redfish Rocks, Cape Perpetua, Cape Falcon, Cascade Head, and Otter Rock) as protected areas.

\subsection{Interaction potential}

We assessed interaction potential between core habitat areas and human activities by quantifying 2 interaction metrics: direct overlap and proximity (Table 4). We measured the percent overlap between human activities and core habitat areas as the proportion of the total abundance of sea otters within core habitat areas that spatially overlapped

Table 4. Description of metrics used to describe interaction potential between core habitat areas and human activities in Oregon, USA

\begin{tabular}{|lcc|}
\hline $\begin{array}{l}\text { Interaction } \\
\text { metric }\end{array}$ & Unit & $\begin{array}{c}\text { Human } \\
\text { activity }\end{array}$ \\
\hline Direct overlap & $\begin{array}{c}\text { Activity within } \\
\text { habitat (Yes/No) } \\
\text { \% habitat } \\
\text { within activity }\end{array}$ & $\begin{array}{c}\text { All, } \\
\text { except ports }\end{array}$ \\
Proximity & $\begin{array}{c}\text { All, } \\
\text { except ports } \\
\text { of habitat (Yes/No) } \\
\text { \% activity (area) } \\
\text { within 2 km of habitat }\end{array}$ & All \\
& & $\begin{array}{c}\text { Fisheries only } \\
\text { (Dungeness crab, } \\
\text { sea urchin) }\end{array}$ \\
\hline
\end{tabular}


with human activity polygons. We also quantified proximity between core habitat area polygons and human activities, reasoning that activities were likely to interact with sea otters if they occurred within $2 \mathrm{~km}$ of core habitat areas, based on reported daily dispersal patterns (i.e. 1 to $2 \mathrm{~km}$ ) of sea otters at all age and sex classes (Ralls et al. 1995). Proximity measures were more appropriate than proportional overlap for certain human activities such as those with point locations (e.g. ports) or diffuse activities. For fisheries, we highlighted potential interactions with relatively high-landing fishing grounds.

All associated datasets and spatial layers are available in an online public data repository (https:// figshare.com/projects/Oregon_Sea_Otter_Carrying_ Capacity_Kone_et_al_2020_/78075).

\section{RESULTS}

\subsection{Carrying capacity and core habitat areas}

We predicted a total abundance of 4538 (17428976; $95 \%$ CI) sea otters at carrying capacity within outer coast and estuarine habitats of Oregon. We predicted higher total abundance and average otter density in the south region on the outer coast. However, within estuaries, we predicted slightly higher abundances in the central region (Table 5). We predicted higher abundances along the entire outer coast (3781 otters) than in estuaries (757 otters). We identified 10 core habitat areas (Fig. 2), mostly in the south region $(80 \%$ of habitats; $742 / 926$ otters). Core habitat areas had an average abundance of 93 otters per polygon, ranging from 8 to 494 otters.

\subsection{Human activities}

All fisheries examined in this study either overlapped with, or were proximate to, core habitat areas, but the interaction potential varied between fisheries. A small proportion of primary Dungeness crabbing grounds, where $22 \%$ of crab are caught along the coast, overlapped with and/or were proximate to core habitat areas (Table 3). Most high-catch crabbing grounds occurred within the central region (Fig. 2), but a smaller proportion of these grounds $\left(2 \% ; 6.18 / 252.42 \mathrm{~km}^{2}\right)$ were within dispersal distance for sea otters, than in the north $(11 \% ; 20.40 /$ $\left.178.30 \mathrm{~km}^{2}\right)$ or south $\left(19 \% ; 21 / 109.71 \mathrm{~km}^{2}\right)$ regions.

Commercial fishermen harvested red sea urchins from 13 harvest areas (Fig. 2), primarily in the south region (north: $29.82 \mathrm{~km}^{2}$; central: $21.39 \mathrm{~km}^{2}$; south: $84.84 \mathrm{~km}^{2}$ ). Most harvest areas overlapped and/or were proximate to core habitat areas (Table 3), but some harvest areas had a greater potential of interacting with foraging sea otters than others. In fact, 5 harvest areas were completely $(100 \%$ by area) within $2 \mathrm{~km}$ of core habitat areas, including Orford, Rogue, and Blanco Reefs, which had the highest total landings $\left(182324,101694\right.$, and 40613 pounds $\mathrm{yr}^{-1}$, respectively), constituting $83 \%\left(3.2 \times 10^{6} / 3.9 \times 10^{6}\right.$ pounds $\mathrm{yr}^{-1}$ ) of all red sea urchin annual landings across the state. The other 2 harvest areas, Nellie's Cove and Mack Reef, only comprised approximately $3 \%\left(1.0 \times 10^{4} / 3.9 \times 10^{6}\right.$ pounds $\left.\mathrm{yr}^{-1}\right)$ of all landings, combined.

Abalone were harvested from 8 harvest zones in Oregon, primarily in the south region. All harvest zones overlapped with, and were proximate to, core habitat areas (Table 3). We found most abalone landings (91\%; 1336/1467 individuals) came from just 2 harvest zones, but only $1.4 \%$ (13/926 otters) of core habitat areas occurred within these zones.

When we considered fisheries as a potential disturbance to sea otters, we found all core habitat areas overlapped with either high-catch crabbing grounds or red sea urchin harvest areas. In total, approximately $76 \%$ (699/926 otters) of core habitat

Table 5. Predicted total abundance and mean $(\bar{x})$ sea otter densities $\left(\mathrm{km}^{-2}\right)$, with $95 \%$ confidence interval (CI), for each region in Oregon, USA. Estuary densities are identical due to uniform estuarine density parameter applied to all estuaries

\begin{tabular}{|lcccccc|}
\hline $\begin{array}{l}\text { Region } \\
\left(\text { area } \mathrm{km}^{2}\right)\end{array}$ & $\begin{array}{c}\text { Total } \\
\text { abundance }\end{array}$ & $\begin{array}{c}\text { Lower CI Upper CI } \\
(95 \%)\end{array}$ & $\begin{array}{c}\text { Density } \\
(95 \%)\end{array}$ & $\begin{array}{c}\text { Lower CI } \\
(95 \%)\end{array}$ & $\begin{array}{c}\text { Upper CI } \\
(95 \%)\end{array}$ \\
\hline $\begin{array}{l}\text { Outer coast } \\
\text { North } \\
\left(1079 \mathrm{~km}^{2}\right)\end{array}$ & 1233 & 473 & 2439 & 1.83 & 0.70 & 3.61 \\
$\begin{array}{l}\text { Central } \\
\left(1175 \mathrm{~km}^{2}\right)\end{array}$ & 997 & 383 & 1972 & 1.74 & 0.67 & 3.44 \\
$\begin{array}{l}\text { South } \\
\left(1005 \mathrm{~km}^{2}\right)\end{array}$ & 1551 & 595 & 3068 & 2.45 & 0.94 & 4.84 \\
$\begin{array}{l}\text { Estuaries } \\
\text { North } \\
\left(63 \mathrm{~km}^{2}\right)\end{array}$ & 233 & 90 & 462 & 3.73 & 1.43 & 7.37 \\
$\begin{array}{l}\text { Central } \\
\left(78 \mathrm{~km}^{2}\right)\end{array}$ & 290 & 111 & 574 & 3.73 & 1.43 & 7.37 \\
$\begin{array}{l}\text { South } \\
\left(63 \mathrm{~km}^{2}\right)\end{array}$ & 234 & 90 & 462 & 3.73 & 1.43 & 7.37 \\
\hline
\end{tabular}



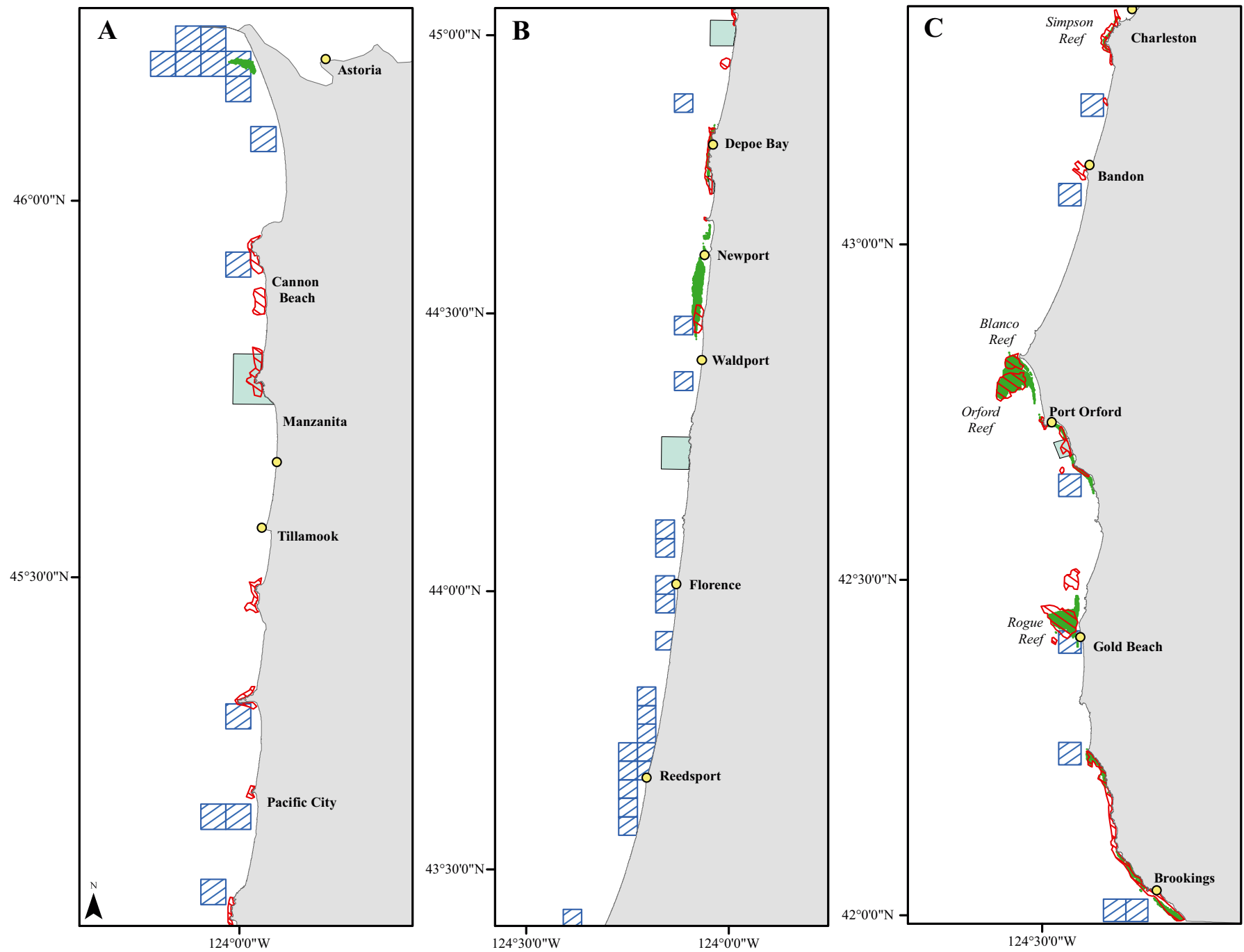

Fig. 2. Spatial location of predicted sea otter core habitat areas (green polygons) along the outer coast and the potential overlap with and proximity of these areas to high-catch crabbing grounds (blue hatched grid cells; data from 2007 to 2017), sea urchin harvest areas (red hatched polygons; data from 2009 to 2018), fishing ports (yellow dots; data from 2011), and marine reserves (turquoise polygons; data from 2010) across regions (A: north; B: central; C: south) in Oregon, USA

areas overlapped with fisheries. We did not include abalone harvest zones in this estimate due to lack of spatial resolution.

By area, most recreation (i.e. human-powered and wildlife viewing) took place in the central region $\left(45 \% ; 606.25 / 1355.52 \mathrm{~km}^{2}\right)$, relative to the north $\left(26 \% ; 357.78 / 1355.52 \mathrm{~km}^{2}\right)$ and south $(29 \%$; 391.49/ $1355.52 \mathrm{~km}^{2}$ ) regions. While core habitat areas did not overlap entirely ( $58 \%$; 536/926 otters) with recreational activity, all core habitat areas did directly overlap with recreational activity to some degree. Most of this overlap occurred in the south $(68 \%$; $365 / 536$ otters) and central (32\%; 170/536 otters) regions. Commercial shipping lanes were located primarily offshore but extend to the shoreline at 5 ports, and tow lanes were scattered across all regions throughout the study area (Fig. A1 in the Appendix). We found no overlap with tow lanes, but a small degree of overlap with commercial shipping lanes (1\% core habitat areas; 9/926 otters). Fishing ports were located across the entire study area. When we considered potential disturbance from all non-recreational sources of potential vessel activity (i.e. fishing ports, commercial shipping lanes, and tow lanes) to core habitat areas, we found most core habitat areas $(\mathrm{N}=7)$ were proximate to some form of vessel activity. Importantly, all $(2 / 2)$ core habitat areas in the central region, and most (5/6) in the south, could be disturbed by some form of vessel activity. 
By combining all potential disturbances (i.e. fisheries, recreation, shipping and tow lanes, ports), we found the vast majority $(97 \%$; 896/926 otters) of core habitat areas overlap with some form of disturbance. Among regions, approximately 1\% (13/896 otters), $19 \%(170 / 896$ otters), and $80 \%$ (714/896 otters) of this potential direct disturbance occurred in the north, central, and south regions, respectively. Within regions, direct disturbance from the evaluated factors could affect approximately 85\% (13/15 otters), $100 \%$ (170/170 otters), and 96\% (714/742 otters) of core habitat areas in the north, central, and south regions, respectively.

The marine reserves in Oregon were somewhat evenly distributed within the study area, including Cape Falcon $\left(32 \mathrm{~km}^{2}\right.$; north region), Cascade Head (25 km ; central region) Otter Rock $\left(3 \mathrm{~km}^{2}\right.$; central region), Cape Perpetua (36 $\mathrm{km}^{2}$; central region), and Redfish Rocks $\left(7 \mathrm{~km}^{2}\right.$; south region). Two of these marine reserves overlapped with, or were proximate to, core habitat areas: Otter Rock and Redfish Rocks marine reserves. Two percent (19/926 otters) of core habitat areas overlapped with Otter Rock ( $<1$ otter) and Redfish Rocks (19 otters). Interestingly, despite the relatively small sizes of Redfish Rocks and Otter Rock, we found they contained the most core habitat areas out of all 5 marine reserves.

\section{DISCUSSION}

We present here the first carrying capacity estimate for sea otters in Oregon. The estimates of potential abundance, based on habitat-density relationships described for California and the distribution of available habitat in Oregon, suggest that sea otters could form relatively abundant populations along the Oregon coast. We have also identified a range of potential human-sea otter interactions that could result in resource competition or disturbance to sea otters. While we show sea otters may interact with people across the entire Oregon coast, we also show some areas of more limited interaction potential where these negative interactions may be limited.

Our carrying capacity and core habitat area findings provide a glimpse into potential future sea otter distribution and abundance in Oregon, but they also corroborate observations of sea otter space use and distribution following the previous translocation effort. Specifically, these results suggest sea otters are more likely to thrive along the southern coastline, supported by greater preponderance of high quality habitat. In the 1970 s, sea otters were observed to routinely forage at Orford, Blanco, and Simpson Reefs along the southern coastline (Jameson 1974). Our current results also suggest that these reefs represent potentially important future habitats for sea otters, providing a total of $24 \mathrm{~km}^{2}$ of core habitat areas within $52 \mathrm{~km}$ of each other. We identified another large core habitat area just south of Newport, OR $\left(21.12 \mathrm{~km}^{2} ; 133\right.$ otters). Together these findings suggest the southern coastline may be more suitable for sea otters, based on habitat alone, with some potentially important habitats along the central coastline, and little along the north coast. While our findings cannot conclusively address whether the 1970s failed sea otter translocation was due to lack of suitable habitat, they suggest this was probably not the case.

Human interactions and disturbance have been suggested as a potential cause of the 1970s failed translocation effort (Jameson 1974). In the present study, we show that sea otters could interact with humans and potentially face disturbance from fisheries, recreation, and various sources of vessel activity (i.e. commercial shipping lanes, tow lanes, and large ports), potentially impacting population re-establishment. These human activities are spatially variable, and we have shown that some activities, like commercial shipping lanes and tow lanes, have a much lower potential of disturbing sea otters, based on the lack of spatial overlap with core habitat areas. Other activities, such as recreation, may be greater contributors to potential sea otter disturbance. We found that most of the core habitat areas predicted to experience disturbance were located within the south region, probably a reflection of the fact that most core habitat areas occurred within this region. Within regions, disturbance could disproportionally impact sea otters in the central region, as all (100\% by area) core habitat areas overlap with disturbance from potential vessel activity, fisheries, and recreation. Yet, sea otter habitat also has a high proportion of overlap with human activities in the north (85\%) and south (96\%) regions. Importantly, these disturbance assessments are only based on spatial overlap with habitats, not intensity. Specifically, commercial shipping lane data does not indicate how frequently ships pass through lanes, recreation data does not tell us how prevalent activities are within planning units, and fisheries landings data does not directly indicate fishing effort. To better understand the potential intensity of fishery disturbance on sea otters, future studies should focus on relating sea otter core habitat areas with fishing effort, not landings. Our fishery disturbance results assume landings are correlated with effort, but this 
may not be the case. If landings and efforts are not correlated, there may be other areas in our study area where sea otters may be disturbed by fishing activity.

Proximity to disturbance is an assessment of potential disturbance to sea otters while foraging within $2 \mathrm{~km}$ of core habitat areas. Our disturbance proximity results should not be interpreted as the distance between a sea otter and disturbance stimuli that elicits a behavioral or physiological response, but rather they should be considered as the areas of the marine environment beyond core habitat areas where sea otters could come into direct contact with humans while foraging. We recognize sea otters are more likely to elicit a behavior response within $54 \mathrm{~m}$ of human activities (Barrett 2019), but this distance estimates the Euclidean distance between the observed location of a sea otter and disturbance stimuli. Our analysis is precautionary as it considers all potential areas where sea otters may interact with humans given their dispersal potential (i.e. within $2 \mathrm{~km}$ ). While foraging, sea otters can disperse further than 2 km (e.g. 4 km; Ralls et al. 1995, Tarjan \& Tinker 2016), but we applied a $2 \mathrm{~km}$ threshold as a conservative estimate given our use of a $4 \mathrm{~km}$ smoothing window that already considers dispersal potential. Therefore, we intended to avoid overestimating dispersal, as this might unrealistically increase our disturbance potential results.

Furthermore, our assessments assume all human activities disturb sea otters to the same degree and, therefore, are equally likely to reduce or limit population reestablishment. This assumption makes our disturbance results highly speculative as (1) we lack knowledge on the relative importance of various forms of human disturbance on sea otter behavior and energetics and (2) research on the populationlevel consequences of human disturbance on sea otters is nascent. Most research has focused on recreation due to the proximity of sea otters to ecotourists (Curland 1997, Benham 2006), and distance from a sea otter to a disturbance stimulus is a good predictor of behavior response probability (Barrett 2019). Given that proximity is a key factor, we expanded our disturbance assessments to other forms of human activities that are proximate to core habitat areas and may elicit similar behavioral and physiological responses in sea otters as recreation. Given our assumptions, direct overlap may be a stronger indicator of potential disturbance and we recommend that further research should address the relative influence of different types of human disturbance on sea otter behavior and energetics.
Resource competition between sea otters and fisheries is a common concern across the sea otter range (Carswell et al. 2015). Our study directly addressed those concerns by assessing potential interactions between sea otters, based on core habitat area distribution, and the Dungeness crab and red sea urchin commercial fisheries in Oregon. We found very little spatial overlap between core habitat areas and crabbing grounds that produce the highest annual landings in the commercial Dungeness crab fishery, which is the most lucrative fishery in Oregon (ODFW 2017a). Based on these results, we suspect sea otters and commercial crabbers may experience relatively limited resource competition and interaction. Dungeness crab is a soft-sediment species (Holsman et al. 2006), which likely explains the lack of spatial overlap between important crabbing grounds and core habitat areas. Many of these crabbing grounds occur in areas where sea otters are predicted to be less dense, and in offshore areas that are beyond the diving capacity of sea otters (Bodkin et al. 2004). Sea otters may interact with the commercial crab fishery in isolated areas, but we suspect they are unlikely to impact or compete with the entire fishery. One limitation of these crabbing-otter interpretations is that they only represent potential interactions with potential adult Dungeness crab population distribution, inferred from fishery landings data. Juvenile Dungeness crabs concentrate in relatively shallow habitats including intertidal zones and estuaries (Fernandez et al. 1993, Armstrong et al. 2003). If core habitat areas spatially overlap with or are proximate to shallow habitats inhabited by juvenile crab populations, sea otter predation on juvenile crabs could potentially reduce adult crab recruitment and eventually impact the commercial fishery. The results of our study do not address this hypothetical scenario, so more research on this potential impact is warranted.

In contrast with the minimal overlap with crabbing grounds, we found a high degree of overlap between the red sea urchin and abalone fisheries and core habitat areas. This finding is perhaps not surprising given the similarities in habitat preferences of all 3 species for rocky reefs (Tegner \& Levin 1982, Kato \& Schroeter 1985). Given the proximity of these highlanding harvest areas to core habitat areas, these results suggest a high potential for interaction with, and impacts from, sea otters for these fisheries. Importantly, sea otters are size-selective predators that target larger individuals within prey populations (Ostfeld 1982). Urchin fisheries also target large individuals, which is likely why there is no evidence of viable commercial red sea urchin fisheries occurring 
within areas occupied by sea otters in other regions. If sea otters are reintroduced to Oregon, it is highly likely Oregon could experience similar declines in large sea urchins, eventually making it difficult or impossible for a commercial urchin fishery to persist in areas where sea otters have recovered. Managers may therefore wish to consider alternative economic opportunities for commercial urchin fishermen and divers, specifically, before they decide whether to proceed with a reintroduction effort. Similarly, abalone population reductions via sea otter predation could also threaten the viability of Oregon's recreational fishery or may even be a conservation concern, given current abalone population declines (ODFW 2017b). However, it is worth noting that abalone in other regions have been found to persist within cryptic habitats, sometimes at elevated densities, in areas having high density sea otter populations (Lee et al. 2016, Raimondi et al. 2015).

Marine protected areas represent one possible approach to minimizing human-sea otter interactions that may lead to disturbance or resource competition. Unfortunately, our analyses suggest that sea otters may be afforded little protection by current marine reserves in Oregon due to limited spatial overlap between core habitat areas and reserves. Protecting the types of habitats important to sea otters was unlikely to have been a priority for managers while establishing the Oregon marine reserves, which could explain these findings. Several other protected areas exist along the Oregon coast (i.e. marine gardens, limited-access protected areas, and national wildlife refuges), but we did not assess these protected areas as they are not fully protected, and monitoring and enforcement are limited. Even if these protected areas only prohibit some human activities some of the time, that exclusion could help protect and preserve potentially important sea otter habitat and could be investigated in future research.

The results of our study come with a few caveats and limitations. First, this study is an extension and an extrapolation of how habitats support sea otter populations in California, but it is uncertain whether Oregon habitats, especially kelp canopies, will support similar equilibrium sea otter densities as in California. The CA model indicates that the presence of kelp canopy is associated with higher sea otter densities; however, those results are likely driven primarily by giant kelp Macrocystis pyrifera, a species which is more persistent (Foster \& Schiel 1985) than Oregon's bull kelp, which experiences intra- and inter-annual variability (Springer et al. 2007). Kelp provides an important food resource for otter prey (i.e. sea urchins, abalone). Reduced kelp could limit prey population size and quality (i.e. mass), which could limit otter densities. Kelp variability could also redistribute core habitat areas from where we have predicted. This limitation highlights the important bottom-up processes that support sea otters and how environmental variability may impact sea otter abundance and distribution. Yet, through their strong topdown pressures, sea otters can help maintain ecosystem function and important habitats, such as kelp, by controlling herbivores, like sea urchins. Recently, northern California (where sea otters have historically occurred, but do not currently) experienced a $90 \%$ reduction in canopy-forming bull kelp due to climatic and biological stressors, with purple urchin grazing being a major contributor (Rogers-Bennett et al. 2019). To date, Oregon has only experienced some kelp cover reductions in isolated locations, nowhere near the extent observed in northern California. Yet, if these events continue to unfold in Oregon, reintroducing sea otters might help limit largescale losses of kelp forests like that which has occurred in northern California. Despite these limitations, we feel our extrapolation of sea otter densities associated with key habitat variables from California to Oregon is appropriate given relative geographic proximity, data availability, and application of this novel approach. To address this limitation, however, future analyses could determine sea otter density and habitat functional relationships in other locations within the current range of sea otters (e.g. Washington, Alaska, British Columbia) to assess how representative the California data may be of Oregon.

A second caveat to our results relates to the projected abundances in estuaries. The densities of estuarine sea otter populations predicted by the CA model are informed by the few currently occupied estuaries in California, specifically Morro Bay and Elkhorn Slough. The former estuary supports a fairly low abundance of otters, while the latter (Elkhorn Slough) supports a very high abundance, apparently sustained by an abundant and productive prey base (Kvitek \& Oliver 1988). The contrast in abundance between the 2 California estuaries leads to a high degree of uncertainty in our model estimate for estuarine habitats. Extrapolation of the model to Oregon estuaries effectively projects an average of the Morro Bay and Elkhorn Slough equilibrium densities, with very large associated standard error. While this approach may be reasonable as a first pass approach, further research is needed to elucidate the potential of Oregon estuaries to support thriving sea otter populations. 
A third limitation of our analyses is that we only identified core habitat area and potential human interactions on the outer coast, not within estuaries and along shorelines. Our findings therefore do not reflect the potential role estuaries and shorelines may play in supporting future sea otter populations, including providing additional foraging habitat and resting areas to haul out (despite this behavior being rare), nor do they capture the potential for humansea otter interactions in estuaries. Sea otters occur in Elkhorn Slough, an estuary in California, with high population density supported by locally abundant clam populations (Kvitek \& Oliver 1988, Maldini et al. 2012, Hughes et al. 2013, Eby et al. 2017). There is also evidence that other California estuaries (e.g. San Francisco Bay, Drakes Estero, and Morro Bay) were historically occupied by sea otters, based on archaeological remains discovered in Native American shell middens and anecdotal accounts of sea otter estuarine habitat use (Schenck 1926, Odgen 1941, Broughton 1999, Jones et al. 2011, Hughes et al. 2019). The potential for California estuaries as future sea otter habitat has recently been considered (Hughes et al. 2019). Sea otters may also thrive in estuaries along the Oregon coast, with relative prey availability likely acting as the primary determinant of population potential. Many Oregon estuaries do contain populations of potential sea otter prey species, particularly bay clams and Dungeness crabs. In fact, in some of the estuaries identified by our model (Alsea Bay, Coos Bay, Netarts Bay, Siletz Bay, Tillamook Bay, Yaquina Bay), bay clam populations have been identified (Ainsworth et al. 2014). To better understand the potential for Oregon estuaries to play a role in supporting a resident sea otter population, future research should investigate prey availability, and human use and presence within and/or near potentially important estuaries.

A final caveat is that our examination of potential human-sea otter interactions in Oregon lacks spatial and temporal resolution. Carrying capacity predictions were calculated using a finer spatial resolution than was available for most of the human activities, specifically commercial Dungeness crab cells, abalone harvest areas, and recreation planning units. The available data indicate approximately where those activities are located but lack spatial precision and are thus representative of very general patterns. Additionally, these interpretations are temporally static. We only considered where core habitat areas are located relative to current human activities, and did not consider seasonal patterns, or the time course from reintroduction to equilibrium abundance. As previously discussed, habitat and biotic features can shift over time due to any number of forces (e.g. climate change, ocean acidification, etc.). Humans may redistribute their activities, such as fisheries and reserves, in response to these ecological shifts, and so the patterns of potential interaction presented here may not hold under such changes.

\section{CONCLUSIONS}

Reintroductions are a well recognized strategy to augment the recovery of at-risk species (Clark \& Westrum 1989, Seddon et al. 2007). A sea otter reintroduction to Oregon could reestablish this once native species and help sea otters recover from previous human exploitation. However, given the risk of another failed reintroduction effort and lack of information to explain that failure, managers have not yet decided whether they will proceed with a reintroduction. To facilitate the decision, we have attempted to address some of the common uncertainties associated with species reintroductions, including habitat suitability. Our analyses indirectly address some of the hypotheses for the cause of failure of the previous translocation effort; for example, our results are not consistent with the 'lack of suitable habitat' hypothesis, suggesting instead that the available habitat could support a population of $>4500$ sea otters. Our study also identified areas of particularly high density, and potential interactions with human activities. Managers could use this information to set reasonable population recovery targets that factor in both ecological and socioeconomic considerations. Lastly, we have investigated the potential to reintroduce sea otters to Oregon from a bottom-up perspective; moving forward, an important next step will be to consider how reestablishing sea otters could change the environment via top-down processes. Reintroducing sea otters could result in negative effects to certain commercial fisheries but could also lead to positive outcomes such as restored kelp habitats and ecological resilience that supports fisheries and tourism operations. As managers consider whether to proceed with a reintroduction, monitoring will be key to understanding how these bottom-up and top-down processes will play out, providing insight into the trade-offs associated with each process, and assessing the ultimate success of the reintroduction effort.

Acknowledgements. We thank ODFW's Marine Resources Program and fishery managers for collecting and synthesizing the fisheries logbook data, specifically E. Perotti, J. 
Ainswoth, K. Corbett, and S. Groth. We also thank T. Bell for supplying the NPP spatial data. We acknowledge the US Fish and Wildlife Service (Award \# F18AC00411) and the National Science Foundation's National Research Traineeship program at Oregon State University for their funding support.

\section{LITERATURE CITED}

Ainsworth JC, D'Andre AF, Vance M, Groth SD and others (2014) Status of Oregon bay clam fisheries, stock assessment, and research. Information Reports Number 201409. Oregon Department of Fish and Wildlife, Newport, OR

Armstrong DA, Rooper C, Gunderson D (2003) Estuarine production of juvenile Dungeness crab (Cancer magister) and contribution to the Oregon-Washington coastal fishery. Estuaries 26:1174-1188

Barnosky AD, Matzke N, Tomiya S, Wogan GOU and others (2011) Has the Earth's sixth mass extinction already arrived? Nature 471:51-57

Barrett HE (2019) The energetic cost of anthropogenic disturbance on the southern sea otter (Enhydra lutris nereis). MS thesis, San Jose State University, CA

Behrenfeld MJ, Falkowski PG (1997) Photosynthetic rates derived from satellite-based chlorophyll concentration. Limnol Oceanogr 42:1-20

Benham D (2006) A multidisciplinary approach to investigating and managing the disturbance of southern sea otters (Enhydra lutris nereis) by recreational activities. MS thesis, University of Nottingham

Bhatia N, Vandana (2010) Survey of nearest neighbor techniques. Int J Comput Sci Inf Secur 8:302-305

* Bodkin JL, Esslinger GG, Monson DH (2004) Foraging depths of sea otters and implications to coastal marine communities. Mar Mamm Sci 20:305-321

Briggs SV (2009) Priorities and paradigms: directions in threatened species recovery. Conserv Lett 2:101-108

Broughton JM (1999) Resource depression and intensification during the Late Holocene, San Francisco Bay: evidence from the Emeryville Shellmound vertebrate fauna. University of California Press, Berkeley, CA

Cardinale BJ, Palmer MA, Collins SL (2002) Species diversity enhances ecosystem functioning through interspecific facilitation. Nature 415:426-429

Carswell LP, Speckman SG, Gill VA (2015) Shellfish fishery conflicts and perceptions of sea otters in California and Alaska. In: Larson SE, Bodkin JL, VanBlaricom GR (eds) Sea otter conservation. Elsevier, London, p 335-367

Cheyne SM (2006) Wildlife reintroduction: considerations of habitat quality at the release site. BMC Ecol 6:5

Clapham PJ, Young SB, Brownell RL (1999) Baleen whales: conservation issues and the status of the most endangered populations. Mammal Rev 29:37-62

Clark TW, Westrum R (1989) High-performance teams in wildlife conservation: a species reintroduction and recovery example. Environ Manage 13:663-670

Costa DP, Kooyman GL (1982) Oxygen consumption, thermoregulation, and the effect of fur oiling and washing on the sea otter, Enhydra lutris. Can J Zool 60:2761-2767

Curland J (1997) Effects of disturbance on sea otters (Enhydra lutris) near Monterey, California. MS Thesis, San Jose State University, CA
Dirzo R, Young HS, Galetti M, Ceballos G, Isaac NJB, Collen B (2014) Defaunation in the Anthropocene. Science 345: 401-406

ํDowning AL, Leibold MA (2010) Species richness facilitates ecosystem resilience in aquatic food webs. Freshw Biol 55:2123-2137

Eby R, Scoles R, Hughes BB, Wasson K (2017) Serendipity in a salt marsh: detecting frequent sea otter haul outs in a marsh ecosystem. Ecology 98:2975-2977

* Elmqvist T, Folke C, Nystrom M, Peterson G, Bengtsson J, Walker B, Norberg J (2003) Response diversity, ecosystem change, and resilience. Front Ecol Environ 1:488-494

*Estes JA, Duggins DO (1995) Sea otters and kelp forests in Alaska: generality and variation in a community ecological paradigm. Ecol Monogr 65:75-100

*Estes JA, Palmisano JF (1974) Sea otters: their role in structuring nearshore communities. Science 185:10581060

Estes JE, Smith NS, Palmisano JF (1978) Sea otter predation and community organization in the Western Aleutian Islands, Alaska. Ecology 59:822-833

Festes JA, Jameson RJ, Rhode EB (1982) Activity and prey election in the sea otter: influence of population status on community structure. Am Nat 120:242-258

* Estes JA, Hatfield BB, Ralls K, Ames J (2003) Causes of mortality in California sea otters during periods of population growth and decline. Mar Mamm Sci 19:198-216

* Faurot ER (1985) Haulout behavior of California sea otters, Enydra lutris. Mar Mamm Sci 1:337-339

* Fernandez M, Iribarne O, Armstrong D (1993) Habitat selection by young-of-the-year Dungeness crab Cancer magister and predation risk in intertidal habitats. Mar Ecol Prog Ser 92:171-177

Foster MS, Schiel DR (1985) The ecology of giant kelp forests in California: a community profile. US Fish and Wildlife Service Biological Report 85(7.2)

* Garshelis DL, Garshelis JA (1984) Movements and management of sea otters in Alaska. J Wildl Manag 48: 665-678

KGarshelis DL, Garshelis JA, Kimker AT (1986) Sea otter time budgets and prey relationships in Alaska. J Wildl Manag 50:637-647

Goldfinger C, Henkel SK, Romsos C, Havron A and others (2014) Benthic habitat characterization offshore the Pacific Northwest, Volume 1: evaluation of continental shelf geology. OCS Study BOEM 2014-662. US Dept of the Interior, Bureau of Ocean Energy Management, Pacific OCS Region

* Green GE, Brueggeman JJ (1991) Sea otter diets in a declining population in Alaska. Mar Mamm Sci 7:395-401

* Greene HG, Yoklavich M, Starr R, O'Connell V and others (1999) A classification scheme for deep seafloor habitats. Oceanol Acta 22:663-678

* Hale JR, Laidre KL, Tinker MT, Jameson RJ, Jeffries SJ, Larson SE, Bodkin JL (2019) Influence of occupation history and habitat on Washington sea otter diet. Mar Mamm Sci 35:1369-1395

Hesselgrave T, Steinback C, Chen C, Sheeran K and others (2011) Shoreside economic analysis for the Oregon territorial sea plan. Report to Oregon Department of Fish and Wildlife. Ecotrust, Portland, OR

Kolsman KK, McDonald PS, Armstrong DA (2006) Intertidal migration and habitat use by subadult Dungeness crab Cancer magister in a NE Pacific estuary. Mar Ecol Prog Ser 308:183-195 
Hughes BB, Eby R, Dyke EV, Tinker MT, Marks CI, Johnson KS, Wasson K (2013) Recovery of a top predator mediates negative eutrophic effects on seagrass. Proc Natl Acad Sci USA 110:15313-15318

Hughes BB, Wasson K, Tinker MT, Williams SL and others (2019) Species recovery and recolonization of past habitats: lessons for science and conservation from sea otters in estuaries. PeerJ 7:e8100

*Hutchings JA, Myers RA (1994) What can be learned from the collapse of a renewable resource? Atlantic cod, Gadus morhua, of Newfoundland and Labrador. Can J Fish Aquat Sci 51:2126-2146

IUCN/SSC (2013) Guidelines for reintroductions and other conservation translocations. Version 1.0. IUCN Species Survival Commission, Gland

Jameson RJ (1974) An evaluation of attempts to reestablish the sea otter in Oregon. MS thesis, Oregon State University, Corvallis, OR

Jameson RJ, Kenyon KW, Johnson AM, Wight HM (1982) History and status of translocated sea otter populations in North America. Wildl Soc Bull 10:100-107

Johnson AM (1982) Status of Alaska sea otter populations and developing conflicts with fisheries. In: Sabol K (ed) Transactions of the 47th North American Wildlife and Natural Resources Conference. US Fish and Wildlife Publications 42, Washington, DC, p 293-299

Jones TL, Culleton BJ, Larson S, Mellinger S, Porcasi JF (2011) Toward a prehistory of the southern sea otter (Enhydra lutris nereis). In: Braje TJ, Rick TC (eds) Human impacts on seals, sea lions, and sea otters: integrating archaeology and ecology in the Northeast Pacific. University of California Press, Oakland, CA, p 243-271

Kato S, Schroeter SC (1985) Biology of the red sea urchin, Stronglocentrotus franciscanus, and its fishery in California. Mar Fish Rev 47:1-20

Kenyon KW (1969) The sea otter in the eastern Pacific Ocean. N Am Fauna 68:1-352

Kreuder C, Miller MA, Jessup DA, Lowenstine LJ and others (2003) Patterns of mortality in southern sea otters (Enhydra lutris nereis) from 1998-2001. J Wildl Dis 39:495-509

Kulm LD, Fowler GA (1974) Oregon continental margin structure and stratigraphy: a test of the imbricate thrust model. In: Burk CA, Drake CL (eds) The geology of continental margins. Springer, Berlin, p 261-283

Kvitek RG, Oliver JS (1988) Sea otter foraging habits and effects on prey populations and communities in soft-bottom environments. In: VanBlaricom GR, Estes JA (eds) The community ecology of sea otters. Ecological Studies (Analysis and Synthesis) 65. Springer, Berlin, p 22-47

Lafferty KD, Tinker MT (2014) Sea otters are recolonizing southern California in fits and starts. Ecosphere 5:50

LaFranchi C, Daugherty C (2011) Non-consumptive ocean recreation in Oregon: human uses, economic impacts \& spatial data. Surfrider Foundation, Natural Equity, Ecotrust, Portland, OR

Laidre KL, Jameson RJ (2006) Foraging patterns and prey selection in an increasing and expanding sea otter population. J Mammal 87:799-807

KLaidre KL, Jameson RJ, Demaster DP (2001) An estimation of carrying capacity for sea otters along the California coast. Mar Mamm Sci 17:294-309

Laidre KL, Jameson RJ, Gurarie E, Jeffries SJ, Allen H (2009) Spatial habitat use patterns of sea otters in coastal Washington. J Mammal 90:906-917
Larson SD, Hoyt ZN, Eckert GL, Gill VA (2013) Impacts of sea otter (Enhydra lutris) predation on commercially important sea cucumbers (Parastichopus californicus) in southeast Alaska. Can J Fish Aquat Sci 70:1498-1507

Lee LC, Watson JC, Trebilco R, Salomon AK (2016) Indirect effects and prey behavior mediate interactions between an endangered prey and recovering predator. Ecosphere $7: \mathrm{e} 01604$

Mackey M (2006) Protecting Oregon's bull kelp. Pacific Marine Conservation Council, Astoria, OR

Maldini D, Scoles R, Eby R, Cotter M, Rankin RW (2012) Patterns of sea otter haul-out behavior in a California tidal estuary in relation to environmental variables. Northwest Nat 93:67-78

* Myers RA, Hutchings JA, Barrowman NJ (1997) Why do fish stocks collapse? The example of the cod in Atlantic Canada. Ecol Appl 7:91-106

National Academies of Sciences, Engineering, and Medicine (2017) Approaches to understanding the cumulative effects of stressors on marine mammals. The National Academies Press, Washington, DC

* Newsome SD, Tinker MT, Monson DH, Oftedal OT and others (2009) Using stable isotopes to investigate individual diet specialization in California sea otters (Enhydra lutris nereis). Ecology 90:961-974

Nicholson TE, Mayer KA, Staedler MM, Fujii JA and others (2018) Gaps in kelp cover may threaten the recovery of California sea otters. Ecography 41:1751-1762

NOAA (National Oceanic and Atmospheric Administration) (2012) Shipping lanes, NOAA, 2012. Electronic Navigation Charts https://www.coastalatlas.net/metadata/ ShippingLanes,NOAA, 2012.htm (accessed June 2019)

NOAA National Geophysical Data Center. (2003a) U.S. Coastal Relief Model Vol.7 - Central Pacific. NOAA National Centers for Environmental Information. https:// doi.org/10.7289/V50Z7152 (accessed Feb 2018)

NOAA National Geophysical Data Center. (2003b) U.S. Coastal Relief Model Vol.8 - Northwest Pacific. NOAA National Centers for Environmental Information. https:// doi.org/10.7289/V5H12ZXJ (accessed Feb 2018)

Norman K, Sepez J, Lazrus H, Milne N and others (2007) Community profiles for West Coast and North Pacific fisheries-Washington, Oregon, California, and other U.S. states. US Department of Commerce, NOAA Tech Memo NMFS-NWFSC-85

ODFW (Oregon Department of Fish and Wildlife) (2005a) Rocky shoreline sections of the Oregon coast, ODFW, 2005. Oregon Department of Fish and Wildlife. https:// www.coastalatlas.net/metadata/RockyShorelineSections oftheOregonCoast,ODFW, 2005.htm (accessed Feb 2018)

O ODFW (2005b) Sandy shoreline sections of the Oregon coast, ODFW, 2005. Oregon Department of Fish and Wildlife. https://www.coastalatlas.net/metadata/SandyShoreline SectionsoftheOregonCoast,ODFW, 2005.htm (accessed Feb 2018)

ODFW (2006) The Oregon nearshore strategy. Marine Resources Program. Oregon Department of Fish and Wildlife, Newport, OR

ODFW (2010) Marine reserves. Oregon Department of Fish and Wildlife, Oregon Ocean Information. https://www. oregonocean.info/index.php/ocean-documents/maps-data/ gis-data/shapefiles/human-1/management-1/marinereserves-2 (accessed Nov 2017)

ODFW (2011) Kelp canopy and biomass survey. Oregon State Wildlife Grant Program. Final Companion Report. 
Marine Resource Program. Oregon Department of Fish and Wildlife, Newport, OR

ODFW (2017a) Oregon commercial fishing industry year 2016 economic activity summary. Version 1.5, April 2017. Marine Resources Program. Oregon Department of Fish and Wildlife, Newport, OR

ODFW (2017b) Oregon postpones 2018 sport abalone season until further evaluation. www.dfw.state.or.us/news/ 2017/12_dec/122817.asp (accessed October 2019)

ODFW (2019) Oregon's commercial marine fisheries. Marine Resources Program. Oregon Department of Fish and Wildlife, Newport, OR

Odgen A (1941) The California sea otter trade, 1784-1848. University of California Press, Berkeley, CA

Ostfeld RS (1982) Foraging strategies and prey switching in the California sea otter. Oecologia 53:170-178

* Pirotta E, Booth CG, Costa DP, Fleishman E and others (2018) Understanding the population consequences of disturbance. Ecol Evol 8:9934-9946

Raimondi P, Jurgens LJ, Tinker MT (2015) Evaluating potential conservation conflicts between two listed species: sea otters and black abalone. Ecology 96:31023108

Ralls K, Hatfield BB, Siniff DB (1995) Foraging patterns of California sea otters as indicated by telemetry. Can J Zool 73:523-531

Riedman ML, Estes JA (1990) The sea otter (Enhydra lutris): behavior, ecology, and natural history. US Fish Wildl Serv Biol Rep 90:1-126

Ripple WJ, Beschta RL (2003) Wolf reintroduction, predation risk, and cottonwood recovery in Yellowstone National Park. For Ecol Manage 184:299-313

Rogers-Bennett L, Catton CA (2019) Marine heat wave and multiple stressors tip bull kelp forest to sea urchin barrens. Sci Rep 9:15050

Sarrazin F, Barbault R (1996) Reintroduction: challenges and lessons for basic ecology. Trends Ecol Evol 11:474-478

Schenck WE (1926) The Emeryville Shellmound, final report. Univ Calif Publ Am Arch Ethnol 23:147-282

Scranton R (2004) Tidal wetlands of Oregon's coastal watersheds. Oregon State University. https://www.coastalatlas. net/metadata/TidalWetlandsofOregonsCoastalWatersheds, Scranton, 2004.htm (accessed Jan 2018)

Seddon PJ, Armstrong DP, Maloney RF (2007) Developing the science of reintroduction biology. Conserv Biol 21: 303-312

Sherman, K, DeBruyckere LA (2018) Eelgrass habitats on the U.S. West Coast: state of the knowledge of eelgrass ecosystem services and eelgrass extent. Publication prepared by the Pacific Marine and Estuarine Fish Habitat Partnership for The Nature Conservancy

Silliman BR, Hughes BB, Gaskins LC, He Q and others (2018) Are the ghosts of nature's past haunting ecology today? Curr Biol 28:R532-R537

Smith DW, Guernsey DS (2002) Yellowstone wolf project: annual report, 2001. USDI National Park Service, Yel- lowstone Center for Resources, Yellowstone National Park, Wyoming, YCR-NR-2002-04

“Soulé ME, Estes JA, Berger J, Del Rio CM (2003) Ecological effectiveness: conservation goals for interactive species. Conserv Biol 17:1238-1250

Springer Y, Hays C, Carr M, Mackey M (2007) Ecology and management of the bull kelp, Nereocystis luetkeana: a synthesis with recommendations for future research. Lenfest Ocean Program, Washington, DC

* Tarjan LM, Tinker MT (2016) Permissible home range estimation (PHRE) in restricted habitats: a new algorithm and an evaluation for sea otters. PLOS ONE 11:e0150547

Tegner MJ, Levin LA (1982) Do sea urchins and abalones compete in California kelp forest communities? In: Lawrence JM (ed) International Echinoderms Conference, Tampa Bay, September 1982. Balkema, Rotterdam

*Thometz NM, Tinker MT, Staedler MM, Mayer KA, Williams TM (2014) Energetic demands of immature sea otters from birth to weaning: implications for maternal costs, reproductive behavior and population-level trends. J Exp Biol 217:2053-2061

* Thometz NM, Staedler MM, Tomoleoni JA, Bodkin JL, Bentall GB, Tinker MT (2016) Trade-offs between energy maximization and parental care in a central place forager, the sea otter. Behav Ecol 27:1552-1566

* Tinker MT, Hatfield BB, Harris MD, Ames JA (2016) Dramatic increase in sea otter mortality from white sharks in California. Mar Mamm Sci 32:309-326

Tinker MT, Tomoleoni J, LaRoche N, Bowen L and others (2017) Southern sea otter range expansion and habitat use in the Santa Barbara Channel, California. US Geological Survey Open-File Report 2017-1001 (OCS Study BOEM 2017-002)

Tinker MT, Yee JL, Laidre KL, Hatfield BB and others (2021) Habitat features predict carrying capacity of a recovering marine carnivore. J Wildl Manag 85:303-323

* Tyack PL (2008) Implications for marine mammals of largescale changes in the marine acoustic environment. J Mammal 89:549-558

US Fish and Wildlife Service (2003) Final revised recovery plan for the southern sea otter (Enhydra lutris nereis). US Fish and Wildlife Service, Portland, OR

Valente A, Valente J, Fonseca C, Torres R (2017) The success of species reintroductions: a case study of red deer in Portugal two decades after reintroduction. Int J Biodivers Sci Ecosyst Serv Manag 13:134-138

Washington Sea Grant (2007) Crabber-tugboat towlane agreement. Washington Sea Grant. https://www.coastalatlas. net/metadata/Crabber-TugboatTowlaneAgreement,WA SeaGrant, 2007.htm (accessed June 2019)

Williams R, Lusseau D, Hammond PS (2006) Estimating relative energetic costs of human disturbance to killer whales (Orcinus orca). Biol Conserv 133:301-311

* Yeates LC, Williams TM, Fink TL (2007) Diving and foraging energetics of the smallest marine mammal, the sea otter (Enhydra lutris). J Exp Biol 210:1960-1970 
APPENDIX
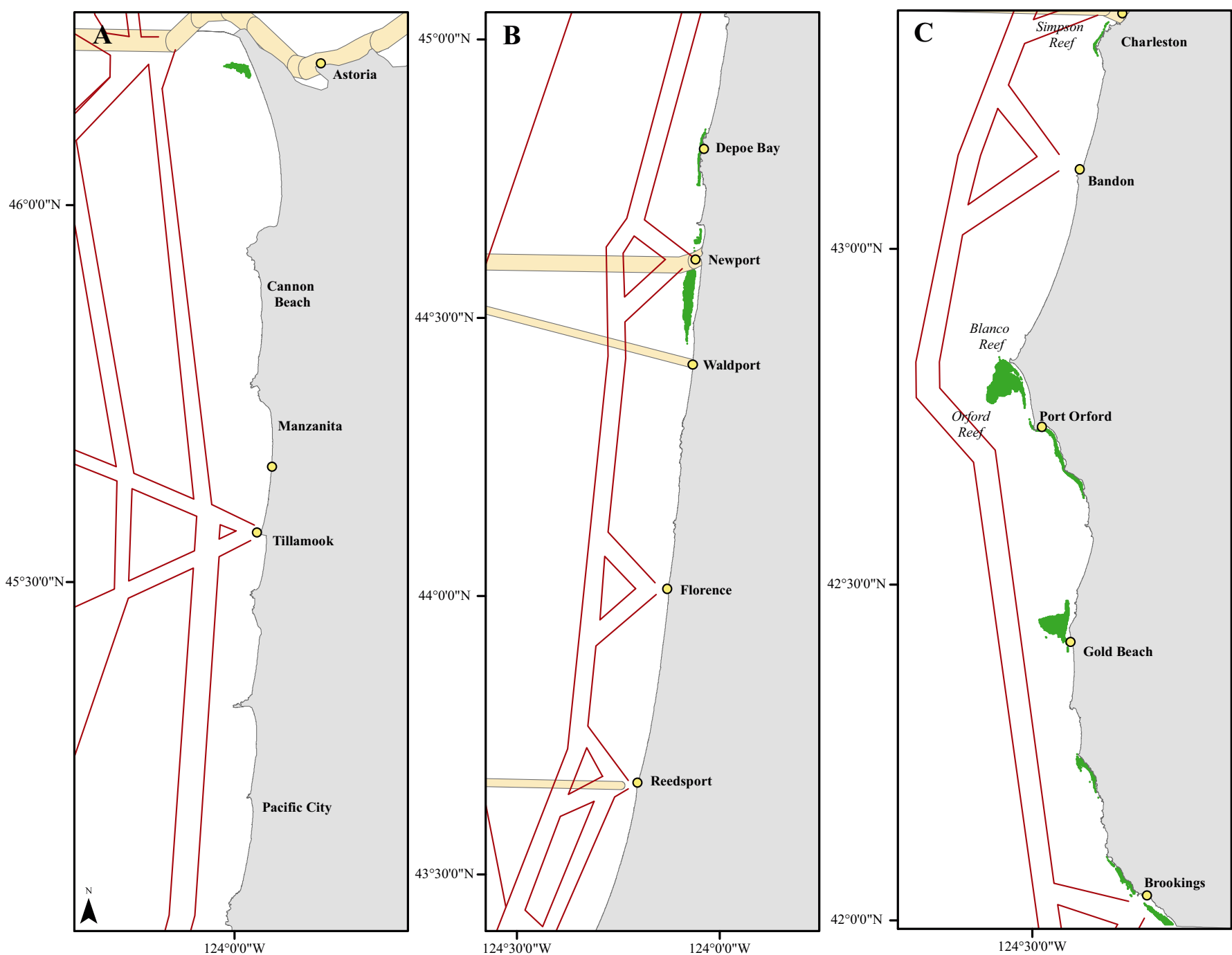

Fig. A1. Spatial location of sea otter core habitat areas (green polygons) along the outer coast and the potential overlap with, and proximity of these areas to, commercial shipping lanes (beige polygons; data from 2012), tow lanes (red lines; data from 2007), and fishing ports (yellow dots; data from 2011) across each region (A: north; B: central; C: south) in Oregon, USA

Editorial responsibility: Jeremy Kiszka, North Miami, Florida, USA

Reviewed by: 3 anonymous referees
Submitted: June 12, 2020

Accepted: December 3, 2020

Proofs received from author(s): February 21, 2021 